

\title{
Alternative Business Models and Entrepreneurship :
}

\author{
The case of Electric Vehicles
}

Paul Nieuwenhuis

\section{Introduction}

While environmental regulation of the car can be traced back to the early 1960s (Watkins, 1991; Lenz and Cozzarini, 1999), in recent years, the combined pressures of reducing toxic emissions as well as emissions of greenhouse gases have brought a new impetus to both environmental regulation of the car and to the technologies needed to address these. In many instances these two agendas call for somewhat contradictory technological solutions, although, frequently, much more of a systems approach than has been used in the past seems the natural path, something that in many respects is novel to the industry. Beyond the automotive industry, the new regulatory climate also calls for changes in the context within which the industry and its products operate, including such areas as changes to existing regulation and the role of government, operating practices, consumer attitudes, and approaches to repair and maintenance.

Thus the past 20 years or so have seen significant advances in both the powertrain and the body/chassis structure areas; lightweight structures using new materials (other than pressed welded sheet steel) and new powertrain solutions are now relatively commonplace compared with even a few model generations ago. The first volume produced hybrids, the Toyota Prius and Honda Insight, were launched in 1997 and 1998 respectively, but now a wide range of hybrids is available. Hybrids have improved, while more advanced versions, using a smaller internal combustion (IC) engine - or 'range extender' - are now also available, as in the Chevrolet Volt and Opel/Vauxhall Ampera as well as being optional on the BMW i3. 'Mild hybrid' and stop-start systems have become commonplace in recent years, while hydrogen fuel cell cars - strictly speaking also hybrids - have been available for lease in limited numbers in Japan and California and were launched for sale by Toyota and Hyundai in several countries in 2016 and 2017 respectively.

Such technologies sounded far into the future even in the mid 1990s, but as a side-effect they have opened up a new space for entrepreneurial activity as typified by Tesla and Autolib, two case studies reviewed in this article, while these have also brought to the industry new, potentially disruptive business models. This contribution will place much of this discussion beyond the merely technological and much more within the context of both the socio-technical transitions and business model literatures. These will be introduced, initially in the context of the response by incumbents in the automotive industry to the EV transition, while exploring the inertia in existing systems, before discussing these two innovative cases. This is then followed by a brief exploration of where other tensions are likely to arise in the transition from an IC to an EV 'regime' with a view to possible future work in this area.

\section{Policy challenges and assumptions}

Much of the move towards greater use of electric powertrain has been driven by government regulation, which, unfortunately has traditionally been informed by a view of the issues surrounding sustainable 'automobility' as primarily, or even solely, technological. Under this approach, consumers can then be informed and will automatically make the 
'right' choice - the largely fictional rational human (homo economicus) of classical economic theory still often informs official thinking. Challenging this notion, the cultural constraints within which consumers make their choices have been highlighted by, for example, Reisch (2005/2006). She argues that merely providing consumers with information is not enough to induce more sustainable behaviour. This argument is shared by Hobson (2001), who challenges traditional positivist policy approaches that provide information and expect consumers to respond with lifestyle changes in a 'rational' manner. Instead she finds in her research that people enter such information in their 'discursive consciousness' contesting certain of the aspects in the evidence presented, while accepting others. Inserting more sustainable practices into people's fiercely protected 'lifestyles' then becomes the real challenge (Hobson, 2001). In this way, many of the barriers to the introduction of new technologies are not technological, but rather sociological, psychological and cultural. Once the technological barriers have been overcome, potential new, entrepreneurial entrants with business models that respond to dissolving those 'softer' barriers can find a way through the traditionally high barriers to entry into what socio-technical transition (STT) thinkers call the automotive 'regime' (Geels, 2002). This STT model introduces the 'multilevel perspective', distinguishing three levels at which innovation plays out; at the top are the landscape conditions, which in this case would include such aspects as the price of oil, the desire for carbon reduction, existing infrastructures. At the bottom level there is a constant trickling of innovative niches, which can embody new technologies, novel business models, or other forms of innovation, challenging the existing regime. Most of these are ultimately unsuccessful and disappear without trace, but under certain conditions, some of these can bundle and successfully challenge the existing regime. For, in between sit existing 'regimes', sets of practices, institutions and regulations that have developed to support a given set of incumbent technologies and the actors that provide them (Geels, 2002). Geels' classic case study describes the gradual transition from sailing ships to steam ships in this context (Geels, 2002). In some cases, actors such as government can also play an active role in promoting such niches, or bundles of niches through a process of 'strategic niche management' (Hoogma et al. 2002).

Marketing techniques such as 'nudging' have also been used by industry and particularly government to overcome any constraints to promote a greener agenda (Peattie, 1995, 1999). As Hart (1997) reminds us, industry - in this case the automotive industry in the broadest sense - also has a fundamental role to play. Clearly, if consumer choice is limited only to environmentally positive choices, the outcomes will be environmentally positive; buyers will only buy green. However, where more sustainable practices already enjoy a measure of social acceptance, such change is more likely. It is important that a more sustainable car type is still appealing; people still have to want it as well as need it - even if such 'needs' are often in the mind of the beholder. For real progress in this area we should therefore look well beyond the technological, yet technology is also our starting point. Sanne (2002) explores the potential for direct government intervention through legal and organizational change, for example, in order to force consumers into specific greener choices analogous with the now widespread ban on smoking in public places.

\section{Electric Vehicle Technologies}

Geels (2005), describes the transition in the transport system from the predominant use of horses to that of cars, but he also highlights the fact that during this transition phase the car featured a number of competing powertrain technologies, notably steam, electric traction and petrol internal combustion. In fact, in the US there was a roughly equal split in terms of market share of these technologies around 1900 (Wakefield, 1993). In Geels' Socio-Technical Transition model, it is shown that 'landscape' conditions at that time, such as the sudden 
availability of cheap oil in the wake of the 'Spindletop' gusher in Texas in 1900, determined that petrol IC won, especially after the invention of the 'self-starter' by Kettering, first offered by Cadillac in 1912. Steam power was ultimately abandoned due to weight, the potential danger of boiler explosion (in reality, largely solved by 1910 due to improvements in metallurgy), but also due to the inherent loss of efficiency of external combustion such as steam, although its advantages were also recognized: high torque from standstill, smooth operation, no need for a gearbox, great reliability. The main problem for EVs, even then, was the range limited by battery capacity and the time it took to charge those batteries, however this did mean that they were considered suited to particular niches, as indeed they have been ever since as in the example of the UK milk 'float' for silent early morning milk delivery and AGVs (automatic guided vehicles) in plants and warehouses, where use of IC would adversely affect air quality. Thus in reality, neither steam, nor EV went away, but became marginalized technologies in the new automotive regime, much like we still ride horses and still use sailing boats. However, with what the transition scholars call 'landscape' changes (Geels, 2002, 2005; Dijk, 2014; Truffer et al. 2017), such marginal technologies, now confined to niches, can become more viable again and that is what appears to be happening to the EV, and to a lesser extent fuel cells (Peters and Coles, 2010).

It is clear, that for the next decade or so we will still have internal combustion (IC) as the dominant technology, although the advent of government policies to ban sales of new internal combustion (IC) engined vehicles, suggested for the UK and China for 2040, Scotland for 2032, while 2025 has been mentioned in the Netherlands and 2020 in Norway, will speed this process. Fossil fuel contains a very large amount of energy for its volume, which makes it difficult to replace as a compact portable energy source. The price of fossil fuel is likely to become more volatile 'post-peak' as recent history has shown, making consumers more insecure, but engine efficiency will keep pace for a while (Heinberg, 2007; Sperling and Cannon, 2007). It should be noted that hybrids and plug-in hybrids still use an IC engine as a range extender, and in many cases hybridization is seen as a way of making IC engines more energy and emissions efficient. In the longer term, these IC engines may give way to a hydrogen fuel cell. This technology has become viable for automotive applications as a result of the entrepreneurial work by Ballard in particular (Koppel, 1999; Peters and Coles, 2010) and is still seen by many as the most promising longer term solution. Yet at present, most hydrogen still derives from fossil fuels, although fuel cell alternatives such as methanol and ammonia can be derived from renewable feedstocks. LPG, CNG and biofuels can also be used in IC engines, which makes those attractive from a toxic emissions perspective. However, such technologies should increasingly be seen as merely postponing the inevitable. For a more durable solution to the issue of transport energy we need to tap more directly into the fresh solar energy that we receive on a daily basis. We need to move away from finite fossilized solar energy and embrace direct solar energy through photo-voltaics, wind power, tidal, wave and similar renewable technologies (Kendall, 2008).

In some respects, the electrification of the car is an inevitable trajectory (Nieuwenhuis 2014, Fig. 12.3). Huber and Mills (2005) argue that a shift towards more electric energy use is inevitable in a broader sense and in line with long term energy trends going back millennia. They point out that energy is effectively unlimited, rather it is our ability to capture it that is limited. Yet some of these technologies also require new infrastructures, which can hamper or delay a transition. Volume produced EVs became available around 2010, with Mitsubishi, Nissan and Renault among the mainstream carmakers leading this trend. This also lent more credibility to more specialist, entrepreneurial EV producers, such as Tesla who are positioning their EVs as premium products, design-led in the way Apple products are 
perceived as premium products. ${ }^{1}$ In reality, a direct comparison of EVs with IC cars is unrealistic; they are a different kind of product and this is how they need to be presented to the market. Modern EVs contain a significant amount of novel technology combined with new esoteric materials; while modern hybrids combine state of the art IC technology with state of the art EV technology. In other words, they are bound to cost more than a conventional IC car - why would we even expect them to be directly competitive on price? Tesla's argument is therefore sound - pay a premium for an EV in the way you pay a premium for an Apple computer.

This does of course require a comparable functionality. And here it gets more complex; although EVs have a different functionality from IC cars, the functionality comparison depends on how you value range, for example, or charging time, against such features as ease of operation, silence in operation, ability to 'fill up' at home, lower maintenance needs, smoother acceleration, or lower running costs. At the same time, one has to accept that from an environmental perspective, only electric vehicles give the option - provided a zero carbon generating mix is developed - of ultimately zero carbon and zero emissions transport, at least at point of use. This is true both for battery-electric and hydrogen fuel cell electric vehicles (FCEV). A number of jurisdictions have introduced specific targets for battery electric and plug-in hybrid vehicles (PHEV). Thus the US is aiming to have one million plug-in vehicles (PIVs) on the road by 2015, China is aiming for five million by 2020 with annual sales of one million by 2020 and a 20-30\% market share by 2030 (Shulock, et al. 2011). Similarly, Japan is planning to have two million FCEVs in use by 2025 , while South Korea is aiming for $50000 \mathrm{BEVs}$ and PHEVs by 2020 with these constituting $50 \%$ of new car sales by the 2030s (Shulock, et al. 2011). Similar targets have been suggested for the EU, but no decision has been made.

\section{New Automotive Business Models?}

\section{Incumbents}

Despite the emphasis on new entrants as a result of such new technologies, thus far, the transition to $\mathrm{EV}$ has seen incumbents as dominant players, certainly in terms of volumes of EVs sold. The main success story in the EV sector has been the established player RenaultNissan, at least in terms of the sheer number of cars built and sold. The Nissan Leaf, in particular, does not embody any radical departure in terms of business model, although Renault at least has sought to separate the battery from the car in terms of ownership and payment, which has seen some success in reducing both the price and the risk to the consumer in terms of new battery technology adoption; batteries typically represent around half the cost of an EV and Renault's offer of batteries for lease has allowed it a degree of differentiation in the market.

Yet, existing mainstream vehicle manufacturers, even those that have launched EVs, have been relatively cautious in their pursuit of innovative business models, initiatives such as the Peugeot Mu concept or the Nissan-Sumitomo 'second life' idea to re-use automotive batteries in static emergency back-up operations notwithstanding. For many vehicle manufacturers, the preferred option seems to be to make EVs as much like traditional cars as possible by driving down battery and system costs and hence reduce purchase price or lease rates for customers. As incumbents, the established vehicle manufacturers have crucial advantages. These include brand recognition, established retail, distribution and support networks; vast experience in marketing cars; the pivotal vehicle integration

\footnotetext{
${ }^{1}$ Even though, unlike Apple products, Teslas benefit in most countries from government subsidies; without these, their pricing would be even more 'premium'.
} 
competencies, political leverage; access to financial resources and comprehensive technical skills. Furthermore, a generally cautious approach has been vindicated by some high-profile failures in terms of business model innovation around EVs, most notably with regard to battery-swap entrepreneur Shai Agassi and his Better Place venture (Christensen et al. 2012), in which Renault had some involvement. Direct experience with EV experiments perceived to have 'failed' have also coloured the approach of some vehicle manufacturers, such as PSA Peugeot Citroen with their EV trials in places such as La Rochelle and Coventry (Obermoller, 2013). Even the 'success' stories of business innovation, such as that of Tesla, explored below, deserve rather more careful evaluation when the industry is considered in an historical perspective (Wells and Nieuwenhuis 2015).

An imaginative model of future, more sustainable, motorized personal transport was proposed by Mitchell et al. (2010) who worked for General Motors. They argued that most growth in car demand this century will take place in the Far East and that the wealthier areas in that part of the world are also increasingly urbanized; a dedicated urban vehicle can therefore be justified. In urban environments, even very extensive ones, average speed and daily mileage for a car is likely to be limited even in these mega-cities, making electric vehicles particularly suited. In addition, the need to reduce toxic pollutants in urban areas, where the concentration of potential victims is so much higher, favours EVs. The small 2seater vehicles proposed by Mitchell et al. (2010) feature autonomous and connected driving and they are fully integrated with their environment, aware of other vehicles and obstacles, thus avoiding accidents and, as a result, the need for heavy crash structures and airbags. To what extent this is still 'driving' is open to debate. Perhaps a model could emerge whereby cars are controlled by the infrastructure in urban areas and on motorways, but by the driver in more technologically challenging rural environments.

Despite the inherent inertia in the car industry (cf. Wells and Nieuwenhuis 2012; Wells et al. 2012; Steinhilber et al. 2013) much of this move is driven - albeit under pressure from legislators - by the mainstream incumbent car companies, notably Renault-Nissan, BMW, General Motors and increasingly others such as VW, efforts from the likes of Tesla and Chinese battery and vehicle producer BYD notwithstanding. This is a major step for the industry. Outside observers often fail to understand that making an EV involves a lot more than fitting a battery and motors to an existing petrol or diesel car. In order to be truly competitive, the EV has to be optimized as an EV, rather than compromised. In addition, the industry has to consider new questions, that bring with them a change in culture, as people ask the question of where the 'fuel' comes from, and particularly its 'green' credentials. Car manufacturers, are now expected to interface with electricity providers, infrastructure providers and they are therefore under increasing pressure to develop new business models, for value is added differently along this newly emerging EV value chain. All this means major, disruptive change, which is why some new, more entrepreneurial entrants such as Tesla can succeed in an industry traditionally featuring very high barriers to entry (Table 1).

Table 1: How EVs Disrupt the Automotive Value Chain (short-medium term)

\begin{tabular}{|l|l|l|l|}
\hline Value chain link & Typical IC & Typical EV & $\begin{array}{l}\text { Examples of } \\
\text { disruption }\end{array}$ \\
\hline Materials supply & $\begin{array}{l}\text { Iron ore, bauxite, } \\
\text { plastics, rubber }\end{array}$ & $\begin{array}{l}\text { Bauxite, plastics, } \\
\text { lithium, rare earths, } \\
\text { rubber }\end{array}$ & $\begin{array}{l}\text { More lightweight } \\
\text { materials; more rare } \\
\text { earths and lithium, } \\
\text { etc. }\end{array}$ \\
\hline
\end{tabular}




\begin{tabular}{|c|c|c|c|}
\hline Component supply & $\begin{array}{l}\text { Engines, } \\
\text { transmissions, cast } \\
\text { iron and aluminium }\end{array}$ & $\begin{array}{l}\text { Motors, controllers, } \\
\text { batteries, pressed and } \\
\text { cast aluminium, } \\
\text { carbon fibre }\end{array}$ & $\begin{array}{l}\text { Phasing out of: } \\
\text { pistons, camshafts, } \\
\text { crankshafts, } \\
\text { gearboxes, fuel } \\
\text { delivery systems, etc.; } \\
\text { need for large } \\
\text { increase in battery } \\
\text { production capacity, } \\
\text { etc. }\end{array}$ \\
\hline Vehicle assembly & $\begin{array}{l}\text { Pressed steel, some } \\
\text { aluminium }\end{array}$ & $\begin{array}{l}\text { Pressed aluminium; } \\
\text { composites }\end{array}$ & $\begin{array}{l}\text { More emphasis on } \\
\text { lightweight } \\
\text { body/chassis } \\
\text { materials: e.g. Al } \\
\text { Tesla, CF BMW I; need } \\
\text { to handle high voltage } \\
\text { systems }\end{array}$ \\
\hline $\begin{array}{l}\text { Sales and } \\
\text { distribution }\end{array}$ & $\begin{array}{l}\text { Largely unskilled sales } \\
\text { staff }\end{array}$ & $\begin{array}{l}\text { Higher skill levels } \\
\text { needed for sales staff } \\
\text { to match customer } \\
\text { with technology }\end{array}$ & $\begin{array}{l}\text { Tesla has integrated } \\
\text { sales and distribution; } \\
\text { BMW, Nissan have } \\
\text { dedicated EV staff }\end{array}$ \\
\hline Aftermarket & $\begin{array}{l}\text { Regular repair and } \\
\text { maintenance; accident } \\
\text { repair; vast network of } \\
\text { informal and small } \\
\text { repair shops }\end{array}$ & $\begin{array}{l}\text { Reduced need for } \\
\text { mechanical repair and } \\
\text { maintenance; still } \\
\text { accident repair; higher } \\
\text { skill levels needed to } \\
\text { deal with high } \\
\text { voltages and new } \\
\text { materials }\end{array}$ & $\begin{array}{l}\text { Accident repair may } \\
\text { reduce as cars become } \\
\text { more connected; } \\
\text { aftermarket repair has } \\
\text { to become more high } \\
\text { skilled and more } \\
\text { specialist; need to link } \\
\text { with energy suppliers. }\end{array}$ \\
\hline End-of-life & $\begin{array}{l}\text { Vehicles highly } \\
\text { recycled ( } 95 \% \text { in EU); } \\
\text { trade in 'cores' for } \\
\text { remanufacturing. }\end{array}$ & $\begin{array}{l}\text { Vehicles highly } \\
\text { recyclable; longer use } \\
\text { phase; battery second } \\
\text { life }\end{array}$ & $\begin{array}{l}\text { New skills needed to } \\
\text { deal with ELV EVs; } \\
\text { new businesses to } \\
\text { manage battery take- } \\
\text { back and re-use }\end{array}$ \\
\hline
\end{tabular}

It is clear from Table 1 that change is to be expected at various points along the automotive value chain and that this suggests that resistance to the changes leading to a transition from IC to EV is inevitable. What is not always appreciated is that such resistance can occur at various points along that value chain, as the industry makes its shift towards new alternative business models (Wells 2008, 2013; Wells and Nieuwenhuis 2015). The resistance to change is not due exclusively to the inertia among vehicle assemblers, who have sunk investments in IC engines, in gearboxes (only BMW and Jaguar among major manufacturers outsource these), but who are also often heavily wedded to the Budd all-steel body system (Nieuwenhuis and Wells 2007). Upstream from these are the suppliers who currently supply around $60-70 \%$ of the value of a new car. It is here that the very existence of some firms is at stake. Although the larger firms such as Continental (once known primarily for tyres but now a highly integrated supplier with increasing expertise in EV components) or Mahle (originally a piston manufacturer, but now emphasizing cutting edge IC technologies such as range extenders and superchargers), smaller firms specializing in specific IC components such as pistons, crankshafts, camshafts or conventional gearboxes could well fail. 


\section{New entrants}

Conversely, new firms with expertise developed outside the automotive sector that is now becoming relevant to that automotive sector may well take their place in a newly emerging value chain. Examples are Google with its growing expertise in autonomous vehicle technology, built on its mapping work, Apple which is increasingly dominant in in-car connectivity, or Panasonic or LG, already major suppliers of traction batteries for EVs to established firms such as GM. Similarly, Chinese firm BYD has shifted its expertise in batteries for portable devices such as cell phones and laptop computers into automotive by setting up its own automotive division offering both IC and electric vehicles, whereby they have become major global players in niche EV technologies such as taxis and buses. On a smaller scale, highly innovative entrepreneurial firms such as Twike, with their lightweight human power-electric hybrid, or Riversimple are presenting themselves at the gates of the industry with both novel technologies - in the latter case a small scale hydrogen fuel cell combined with ultra lightweight body-chassis structure - and radical new business models (Wells, 2016; Riversimple 2017). Most high profile among these new entrants is Tesla, while the way in which the shift to EV can generate novel business models can also be further illustrated by Autolib in France; these are discussed in more detail below.

\section{Emerging Automotive Business Models}

Without delving too deeply into the business models literature (relevant contributions here are, e.g. Bohnsack et al. 2014, Wells, 2013, although more generic work on business models could also be cited), for the purposes of the present analysis, the essence of the emerging automotive business models is, first of all, where along the automotive value chain value is captured - leaving aside for the moment the implication of linearity in the term value 'chain' for a phenomenon that in reality is often more complex and web-like - and how that value is captured by a particular firm. In this context, it is not only the car itself that needs to evolve, the way we use it needs to be subject to a similar evolution as part of new business models (e.g. Wells, 2008, 2013). This often involves players in acquiring new knowledge outside their existing areas of expertise (Rajala and Westerlund, 2007). The existing automotive value chain has been developed over the past 130 years or so and could be summarized in simplified form as in Figure 1.

\section{Figure 1}




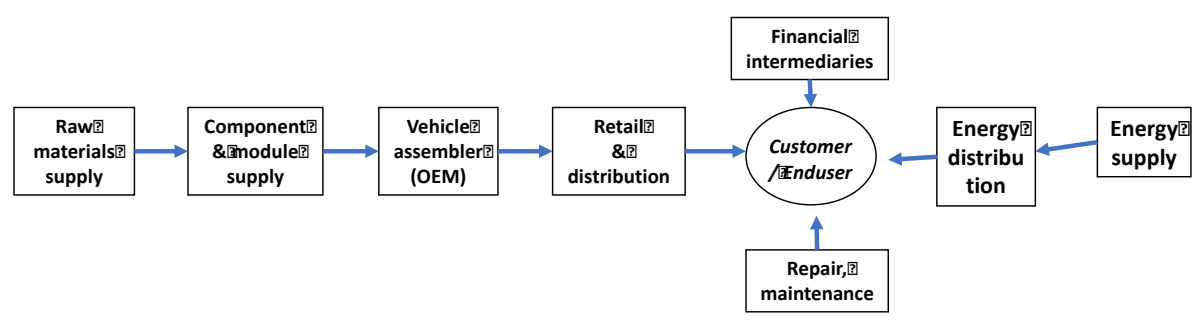

The existing, established volume car producers capture only part of this value chain, as outlined in Figure 2. The box captures the typical activities of existing OEMs in the IC car regime. The very high level of vertical integration Henry Ford adopted in order to support his pioneering mass production system (cf. Nieuwenhuis and Wells, 2007) was gradually disintegrated as a supply sector grew up that was able to support the volumes needed to feed his mass production system and that of an increasing number of other, competing players, notably GM and Chrysler. In addition, retail and distribution are almost always carried out primarily by independent firms, although manufacturers may retain some dealers in prime sites. Where manufacturers do often still retain an interest is in vehicle finance. The box labelled 'financial intermediaries' captures not only such finance companies, but also leasing firms and the growing numbers of car clubs and other car sharing models, such as those operated by daily rental companies, which are themselves also part of this group.

\section{Figure 2}

Conventional圆CAM:

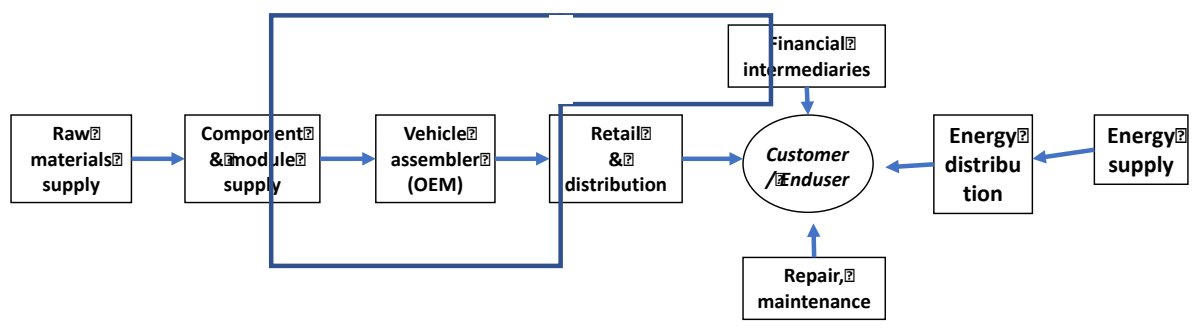


Tesla's first car was the Roadster, essentially a modified Lotus, built by Lotus in the UK and fitted with Tesla's novel battery pack made up of an array of laptop batteries; a technology that has since been shared with other manufacturers. Despite some teething problems, the cooperation with Lotus allowed Tesla to acquire new expertise in vehicle integration, while it also recruited staff from existing car makers to build on this (Rajala and Westerlund, 2007). With the introduction of the Model S in mid-2013, Tesla became synonymous with entrepreneurial success in the emerging EV market. This new electric luxury car was immediately well received by the specialist media and by customers (van Gilluwe and Rogers, 2014). It was also accompanied by a novel highly integrated business model, as outlined in Figure 3.

\section{Figure 3}

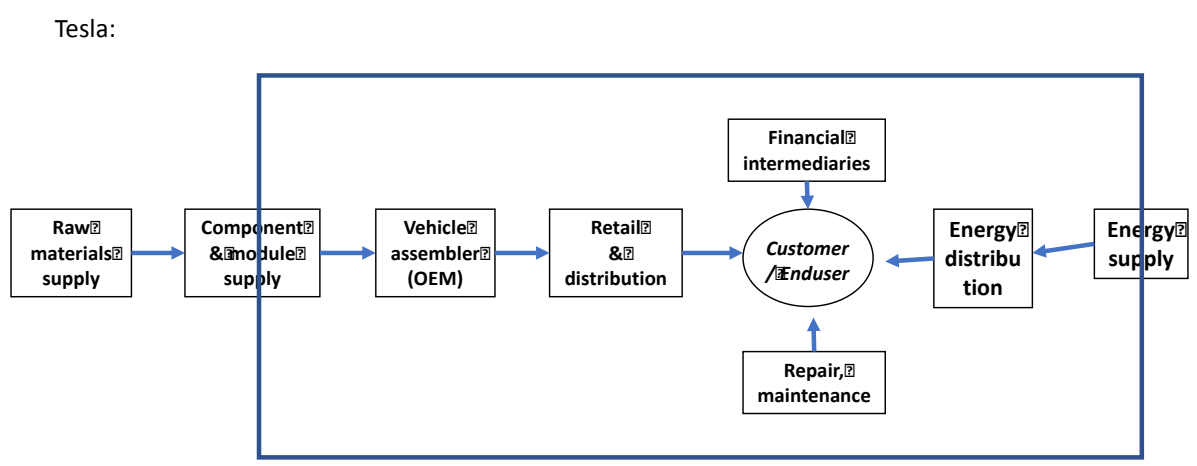

Tesla's value chain capture includes the production of the battery pack, for which it is building its 'Megafactory' in Nevada. It further includes vehicle assembly along similar lines as used for conventional luxury cars, albeit with higher than usual aluminium content, while the car is also built on what constitutes a separate chassis which incorporates the battery pack. Assembly takes place in a former GM-Toyota joint venture plant at Fremont, Northern California. In addition, the Tesla business model captures retail and distribution in that the firm, unusually, owns all its own dealers and sales outlets, which also handle repair and maintenance, while finance is also handled direct. Beyond this, Tesla ensures its own energy distribution for all its cars through a dedicated charger network and it has moved into energy generation via solar panels through its Solar City subsidiary, although Teslas can also be charged on other networks, hence the partial capture of that box in the figure. Such a level of vertical integration has not been seen in the automotive industry since Ford's pioneering days. Not surprising, perhaps, this approach appears more in-line with Silicon Valley precedent such as Apple, than automotive companies. It has also been able to finance this potentially high risk venture because a new generation of investors, more used to internet-based firms with largely virtual assets than the fixed assets that dominate the automotive sector, are used to valuing a company on its potential rather than its actual current value, as already seen with firms such as Facebook, Google or Amazon. It is also worth noting that both the Autolib (see below) and Tesla models involve much greater 
'ownership' of the customer, as she/he is surrounded by a set of services and interfaces controlled directly by these firms.

\section{Autolib}

Although the Tesla business model breaks away from that of incumbent firms, particularly in its level of vertical integration, it still largely reproduces the prevailing automotive regime in terms of private ownership and 'usership' of cars. ${ }^{2}$ By contrast, other new entrants are developing more radical business models that are based around product-service systems (Williams, 2006; Cook 2018). Important developments in this area include car sharing schemes, or car clubs, and 'sale of service' business models, such as the one adopted Welsh hydrogen fuel-cell start-up Riversimple (Wells, 2016; Riversimple 2017).

Autolib is an example of this newly emerging business model in that it involves a car sharing scheme in Paris and its surrounding lle de France region, using a dedicated design of EV. It is run by the Bolloré Group, a family-owned business, founded in 1822. Their main interest in EVs derives from their battery expertise, a unique design of lithium metal polymer (LMP) battery, for which they hold all the patents and which is built by their Batscap division. It has no liquid electrolyte and with an operating temperature of between 60-80 degrees $C$ it means it operates at a stable temperature, so no cooling system is needed and it works at all ambient temperatures. The company found a development partner in CeComp in Italy, who developed the car, the Bluecar, which was designed and built by Pininfarina as a subcontractor to CeComp. More recently Bolloré have linked up with Renault for the development of future vehicles.

Groupe Bolloré won the Autolib tender, issued by the City of Paris and its fellow local authorities in 2011, with the Bluecar. It was able to combine the vehicle with its in-house data management and automated interface terminal maker IER, which is a world leader in terminals for public services (e.g. automated check-in at airports). It was also able to use its in-house telecoms consultant Polyconseil. For the first time, therefore, Bolloré was able to meet a market requirement by combining its various, apparently disparate, areas of activity and expertise in the creation of a new business model. In addition, it developed new relationships with outside firms to plug any gaps in its expertise, such as in vehicle development and integration. By this process it also acquired new knowledge in the pursuit of its new business model (Rajala and Westerlund, 2007). Autolib covers 47 local authorities in the lle de France, with Paris at the centre. The project runs around 4000 cars and employs more than 1200 people. Each Autolib station has 4-6 spaces, and a terminal for signing in. Like other European cities, such as London, Paris has a particulate and NOx pollution problem due in no small part to the widespread use of diesel cars. This means they often breach EU air quality limits; Autolib with its zero emissions EVs helps address this. The average rental of a car from Autolib is about $40 \mathrm{mins}$ and $10 \mathrm{~km}$ for Premium (=annual) subscribers. Monthly subscribers tend to use the cars about 3 hours each rental. The IT solution will find a parking/charging space either automatically or via the call centre which is also part of the scheme; the central control/call centre at Vaucresson in suburban Paris, works 24/7. Running a small car in Paris would normally cost around $€ 2600$ a year, which compares unfavourably with the Autolib subscription. Paris is not a car-friendly city, which helps people shift from their own car to Autolib, which guarantees a parking space, for example.

\footnotetext{
2 Do note that many cars are not sold to end-users, but are leased or provided by some other financial mechanism, by which the end-user is still the sole user, albeit not the actual owner of the car.
} 
Figure 4

Autolib:

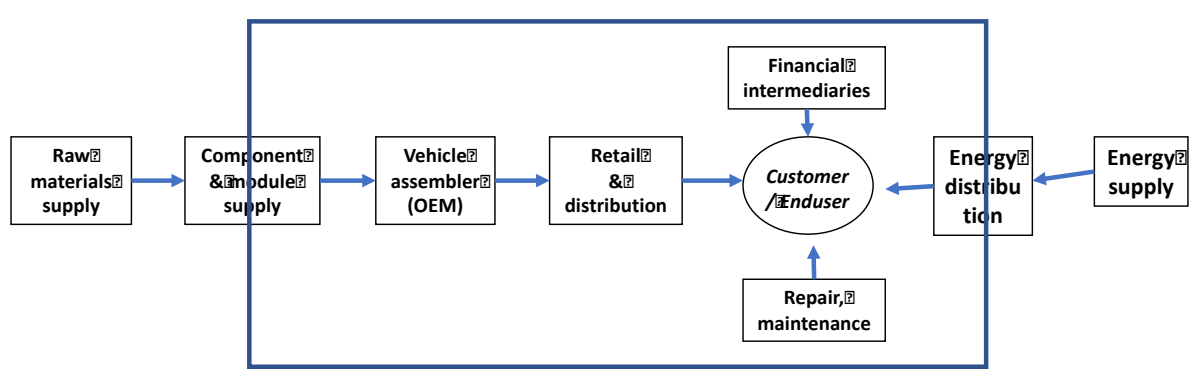

Figure 4 is an attempt to summarise the Autolib business model. Autolib controls a key component, as with a conventional car maker, in that it supplies the battery and controls the design and manufacture, even though these are subcontracted. It also controls its own distribution and deals direct with the end user. Autolib also takes care of the financial side of the project and runs its own energy distribution via its Autolib charging network. In this sense, then, Autolib captures a much larger part of the value chain than conventional car companies.

\section{Transitioning to an EV regime}

Downstream from the assemblers, changes are also to be expected, as dealers and the recovery and vehicle repair sector need to acquire new skills to deal with EVs. The aftermarket sector, as a whole, will also see firms fail that are too reliant on IC technology, while new firms with EV expertise will replace them. Institutional and regulatory changes will also be needed as current government legislation in most respects is based on the assumption of particular vehicle configurations and technologies, which have become integral parts of the current automotive 'regime' (cf. Geels, 2002, 2005; Wells et al. 2012). In addition, governments at national and local level have experienced policy challenges with regard to EVs, particularly where the agenda has been to leverage investments in local charging infrastructures in order to attract investment from the EV manufacturing sector. Many local authorities operate planning rules that make the installation of charging points challenging. Similarly, government support in terms of R\&D programs and other incentives has some political traction but is inevitably also seen as controversial; the media debate in the US over battery technology pioneer A123 Systems and luxury hybrid-electric car producer Fisker continues even today. Both were recipients of US government funding and were subsequently declared bankrupt; highlighting Mazzucato's (2013) notion that government can take risks where private sector players cannot. Similarly, the ongoing debate about the cost of incentives for EVs in Norway. As a consequence, there is a sense in which there is an apparently lucrative market with high growth potential, but which needs a judicious choice of business models at the right time, in the right place, and with the right 
combination of participants in order to unlock those opportunities. Such moves are preliminary to any shift in the 'regime' from the current IC-dominant system, to one where EV is dominant (Dijk, 2014; Truffer, et al. 2017).

On the face of it, the benefits of EVs in reducing GHG emissions in areas with high carbon generating capacity - such as China - is more limited. Yet electric powertrains have a number of inherent environmental advantages over existing IC engines and proposed IC alternatives such as biofuels, CNG or LPG. Over time, these liquid fuels will become higher in carbon content due to increasing use of CTL (coal-to-liquid) and also the increasing proportion of fuels derived from tar sands (O'Sullivan, 2017). At the same time, electricity generation is likely to become lower in carbon as a result of the growth in renewables such as wind, solar, tidal and also geothermal and nuclear power. Kendall (2008) argues, therefore, we should reduce our dependence on liquid fuels in any case, as the potential for electricity to become increasingly zero emissions on a 'well-to-wheel' basis is inevitably much greater than that for fossil fuels and even biofuels. This alone will increasingly serve to support the $\mathrm{EV}$ in favour of $\mathrm{IC}$, as the need to reduce carbon from our economies and toxic emissions from our environment - particularly in urban areas - becomes a more pressing policy and public health priority. However, the challenge now is how to introduce EVs to the public and also at what speed can they and their infrastructure be rolled out? This could logically lead to business models that bundle EVs with energy generation, distribution and supply.

EVs are still often seen as primarily an urban solution, however more recent research has shown that EVs can be equally useful in rural settings (Newman et al. 2014a,b,c). In much of rural Europe, the distance from a typical farm or village to the nearest market town and back is normally well within the range of an EV, and other types of alternative short range vehicle, such as the VSPs ('voitures sans permis' - as in France many can be driven without a driver's licence) popular in rural parts of France - so called L-Category microcars - are also primarily found in rural areas, despite their limited range. The need for personal motorised mobility is greater in rural areas, where regular public transport links are often unfeasible. Rural areas are also often well placed to generate electricity using zero carbon technologies such as micro-hydro, wind or solar due to the availability of land to locate such infrastructure. Several rural EV initiatives are taking place from Bavaria, California and Denmark to Wales to underline this point (Newman et al. 2014). EVs can therefore find application much as current IC cars and in such a context can offer opportunities to local entrepreneurs able to combine renewable energy supply and distribution with EV support in a rural area. It should be noted, however, that in the light of slow replacement demand, it will require many years to transform the stock of cars in circulation to $\mathrm{EV}$ and reap the full benefits in terms of zero or reduced emissions; IC bans from urban areas could well help in this respect by at least cleaning the air where large numbers of people are present. It should also perhaps be noted that EVs currently use several materials and technologies that may themselves be in short supply within a generation and that may in fact create new and possibly unforeseen environmental problems - the constant research into and search for possible alternatives is therefore crucial.

However, the generating aspects should also be highlighted. EVs, combined with new technologies for renewable power generation offer the opportunity of a disruptive change in several of our systems. Power generation tends to be a very centralised industry, dependent as it has historically been on high investment in large power stations, whether coal, gas, or nuclear powered. Although this is still true also for major hydro, wave or tidal projects, both solar and wind, as well as micro-hydro technologies, offer the opportunity for a highly decentralised power generation capacity, which is also much more scalable, as capacity can 
be added in small increments as, when and where required. For EVs this also provides new opportunities, which are particularly realisable in rural areas where land is available for such technologies. IC does not provide this option, as it would require not only an oil-well in one's backyard, but also a refinery. This energy transformation would form an important element of the new EV business model, which could therefore be disruptive not only in automotive terms, but also in energy terms and will provide new scope for entrepreneurial entrants into the energy generating, supply and distribution business.

McKinsey (2009) argued that carbon emissions from IC can be significantly reduced, but ultimately the scope here is limited by certain inherent characteristics of internal combustion technology. Only EVs give the option - provided a zero carbon generating mix is developed - of ultimately zero carbon and zero toxic emissions transport. Under McKinsey's 'hybrid-and-electric' scenario, a $49 \%$ reduction in $\mathrm{CO}_{2}$ emissions is obtained, compared to their baseline scenario. This amounts to a $22 \%$ reduction compared with 2006 global emission levels. This scenario assumes a mix of vehicles with a number of different powertrains. Moving the whole of the global vehicle fleet to electric would amount to an $81 \%$ reduction in well-to-wheel carbon emissions by 2030 , compared to their baseline scenario (McKinsey, 2009). ${ }^{3}$

An earlier McKinsey study (McKinsey, 2003) found that the car industry typically reduces costs per car by around $€ 3000$ every 13 years (= roughly two model generations). At the same time, manufacturers typically add around $€ 4000$ of content to vehicles. This leads to a gradual increase in vehicle costs, but for Europe at least, the overall picture for all three electric technology options turns out better than for North America or Asia, because of historically high fuel costs. Thus both HEV and PHEV provide the owner with a net benefit over the first five years of ownership compared to IC while, for the same reason, the additional cost of a BEV is lower in Europe than in North America, Japan, or China (McKinsey 2009: 20). In addition, some of the increase in content could be provided by electric powertrain as it offers a range of user benefits, including home charging, energy storage as part of a smart grid system, lower NVH (noise, vibration, harshness) levels, improved acceleration, lower maintenance, etc. This could partially compensate for the higher cost of the technology; so higher cost, but also more content and value.

\section{Discussion}

Apart from Ford in the period 1914-1940, Tesla's business model is not quite as novel as has been argued and certain elements of it at least could be said to have precedents (Wells and Nieuwenhuis 2015). They argue, for example, that Smart and others have pre-figured many of the business model innovations offered by Tesla, including (with Daewoo) fixed price or 'no-haggle' sales. Like Tesla, Smart, at the time of its introduction in 1997, embodied a high risk strategy for Daimler-Benz in that it simultaneously included a radical new vehicle concept aimed at an untried and untested market segment, combined with a radically new factory of unusual design and operation. In addition, this led to new supplier relationships involving a small number of system integrators co-located with the assembly plant, as well as a new distribution and sales approach, which included a new brand. Initially at least, this also included mobility packages including tie-ins with rail service providers, and a focus on 'green' consumers. Likewise, Tesla's Powerwall system interfacing between car and house, is similar to systems already offered by Mitsubishi, Nissan and Toyota in Japan, while Toyota even offers the kit-house to go with it.

\footnotetext{
${ }^{3}$ The various reports published by the McKinsey consultancy carry considerable weight in this context and are used both by industry and government.
} 
Other vehicle manufacturers have attempted to make major shifts in their value capture. Ford, for example, in around 2000 under Jac Nasser attempted to shift the centre of gravity of the business downstream by buying into, among others, fast-fit outlet KwikFit and vehicle dismantling operations in the US to control the supply of used parts. The project was rapidly abandoned. During this period Ford also bought Norwegian EV maker Th!nk Nordic, although it too was subsequently sold. The Tesla business model, however, also benefits from other revenue streams, such as the income Tesla obtains selling zero emission credits to others (at one stage amounting to 12 per cent of revenues), and selling battery packs to Daimler for the electric version of the Smart used in the innovative Car2Go schemes and Toyota for the PHEV version of the RAV4 (Wells and Nieuwenhuis, 2015). Both Daimler and Toyota have invested in Tesla in the past.

As illustrated by figures 3 and 4, then, EV business models currently differ significantly from the more traditional IC business model. Whether this is a permanent feature, or a shortterm feature as key players position themselves such that they can identify and benefit from any areas that may be potentially profitable in order to then outsource any other activities to third parties, or whether this picture shows a long term business model format is as yet unclear. We are essentially in a transition period and it is too early to tell what business models may emerge from the present phase. As Rajala and Westerlund (2007) argue, business models evolve dynamically and a firm's business model presents a snap-shot, representing the activities of the business at a specific point in time. However, even in a period of flux, where some of these alternative business models are seen to work, they can be very disruptive of more established models, if only by making people question the validity of those established models.

It is also important to note that both these business model case studies feature involvement by the public sector. EVs are not yet truly 'market ready' and still rely to varying extent on government, either through R\&D support or market incentives. Although not apparent from the figures, this is currently a fundamental part of all EV business models. Thus, while Autolib was created in direct response to a local government tender, Tesla obtained a US\$465 million government loan on generous terms while the initial public offering in 2010 raised only US\$226 million. While Tesla repaid the loan almost ten years early, in 2013, that initial vote of confidence from Federal funds helped underwrite the expansion of the business at the Fremont assembly plant and encouraged other investors to commit. This is an important issue for the future of government intervention. It is apparent that simple reliance on 'the market' to bring forth appropriate solutions is not always feasible in this context. Indeed, it has often been government or public-funded R\&D (including that conducted at universities) that has generated most of the key technological breakthroughs of the contemporary era, from decoding the human genome to the creation of the Internet. Equally, government helps frame the market in important ways through fiscal arrangements, regulatory interventions and the ability to underwrite long-term structural investments (Mazzucato 2013). Such actions then create the space within which entrepreneurs can enter, develop new markets with new business models that potentially disrupt established regimes.

\section{Conclusions}

Business models in the EV world are still emerging and evolving, as they must do in response to shifting contexts. One point that emerges from this analysis is that the notion of a business model needs to extend well beyond the formal boundaries of the business itself; and beyond the boundaries of a particular point in time. Not only should it take a full value chain perspective, extending into wider networks, but it should also ultimately include a consideration of context and environment, or 'regime' (Geels, 2002), particularly in the role 
of government. It should also be emphasized that EV business models are still emerging; they are by no means fully formed and should in any case be considered dynamic entities, as highlighted by Rajala and Westerlund (2007). Companies like Bolloré have the resources and the insight to aim at the long-term prize, so it would be a mistake to rush to judgment on an unfinished strategy. In fact, their current approach is more about assessing where in the section of the value chain money can be made and which are thus worth retaining in-house, and then gradually outsourcing those activities, or links in the chain, where others are better placed to capture value.

On the other hand, as Wells and Nieuwenhuis (2015) and in a broader context Mazzucato (2013) argue, perhaps the state also needs to be more innovative and to take more risks, but also to be more interested in sharing the rewards if those risks are then translated into success. In this sense, perhaps, the state needs to act more like an investor, and in so doing can perhaps channel the rewards of investment back into further risk underwriting activities thereby fostering a more entrepreneurial climate in the economy. The business models literature tends to rather underplay the role of the state as a pivotal agency defining market possibilities, and yet a business model in a sector like that for EVs that ignores the role of the state is at best only partial. The state at national and international level is pivotal in regulatory framing, and in steering developments that are critical to the success or failure of EV business models, currently often through incentives, for example or facilitating charging infrastructures. In the longer term, the incremental extensions of EV business models either backwards or forwards along the value chain may come to be seen as temporary expedients, as already suggested for Groupe Bolloré.

Alternatively, these developments and the emerging business models may ultimately come to facilitate the realization of the circular economy. One thing that seems obvious at the moment is that making more than 70 million cars a year worldwide is unsustainable by any measure. This will be even more the case with increasing electrification of the powertrain, as the embedded carbon then becomes greater than the carbon emitted in use (Hawkins et al. 2012). So, the cars we do make, whatever they are like, will have to be made in smaller numbers and last significantly longer (Nieuwenhuis 1994, 2008). Modularity was a feature of the car in its early days where chassis and body were often sourced from different suppliers direct by the customer and this may be a way forward. Engines and transmissions are still to a large extent modular and can be upgraded relatively easily. New developments such as 3D printing also open up avenues for customization and upgrading either by the owner, or in behalf of the owner by local specialists. Such developments could also open the door to more radical new business models such as micro-factory retailing (Nieuwenhuis and Wells, 2003; 2009; Wells, 2013; Nieuwenhuis 2014).

That the car should be smaller and lighter is clear, in line with Amory Lovins' Hypercar concept, although it will still need to be tough enough to last several decades; and capable of development. This may require different ways of making cars; a few cars are possible pointers to such future cars, notably products like the Gordon Murray Design T25 and T27, Riversimple Rasa, Axon, Twike, but also Tesla, Nissan Leaf, Renault Zoe and Twizy, Smart, the original Insight from Honda, and the BMW i3. The latter is significant in that it is not 'just' an $\mathrm{EV}$, but also introduces a new way of making cars. In a sense it reintroduces modularity in that it has a separate carbonfibre body structure fitted to an aluminium chassis. This gives the potential to mix and match different body and chassis units. In addition, cars will become ICT platforms for which suppliers develop 'apps'. Each customer/owner would choose apps useful for his or her type of car use, while other apps would not be used. Thus future cars will need to be lighter, more durable, more reconfigurable and adaptable, more 
integrated with their infrastructure and in many cases shared. They are also most likely driven by electricity, either directly stored on board, or generated on board by some kind of range extender or fuel cell, or possibly supplied by the infrastructure as they are driven along.

\section{References}

Bohnsack, R., Pinkse, J. and Kolk, A. (2014) Business models for sustainable technologies: exploring business model evolution in the case of electric vehicles, Research Policy, 43 (2) 284-300.

Christensen T, Wells PE, Cipcigan LM, (2012) Can innovative business models overcome resistance to electric vehicles? Better Place and battery electric cars in Denmark, Energy Policy, 48, 498-505 ISSN 0301-4215 10.1016/j.enpol.2012.05.054.

Cook, M. (2018) Product service system innovation in the smart city, International Journal of Entrepreneurship and Innovation, 19 (1), xxx-xxx.

Dijk, M. (2014), A socio-technical perspective on the electrification of the automobile: niche and regime interaction, International Journal of Automotive Technology and Management, 21, 14(2), 158-171.

Geels, F. (2002), 'Technological transitions as evolutionary reconfiguration processes: A multi-level perspective and a case study', Research Policy, 31 (8/9), 1257-1274.

Geels (2005), 'The dynamics of transitions in socio-technical systems: A multi-level analysis of the transition pathway from horse-drawn carriages to automobiles (1860-1930)', Technology Analysis \& Strategic Management, 17(4), 445-476.

Hart, S. (1997), 'Beyond greening: strategies for a sustainable world', Harvard Business Review, Jan-Feb, 66-76.

Hawkins, T., B. Singh, G. Majeau-Bettez and A. Hammer Strømman (2012), 'Comparative environmental life cycle assessment of conventional and electric vehicles', Journal of Industrial Ecology, 17 (1), 53-64.

Heinberg, R. (2007) Peak Everything; Waking up to the Century of Declines, Gabriola Island, BC: New Society.

Hobson, K. (2001), 'Sustainable lifestyles: rethinking barriers and behaviour', in J. Murphy and M. Cohen (eds.), Exploring Sustainable Consumption; Environmental Policy and the Social Sciences, Oxford: Elsevier, 191-209.

Hoogma, R., Kemp, R. Schot, J. and Truffer, B. (2002) Experimenting for Sustainable Transport. The Approach of Strategic Niche Management, London: EF\&N Spon.

Huber, P. and M. Mills (2005), The Bottomless Well; The twilight of fuel, the virtue of waste and why we will never run out of energy, New York: Basic Books.

Kendall, G. (2008), Plugged In; The end of the oil age, WWF: Brussels.

Koppel, T. (1999), Powering the Future; The Ballard Fuel Cell and the Race to Change the World, Toronto: John Wiley \& Sons. 
Lenz, H. and Cozzarini, C. (1999) Emissions and Air Quality, Warrendale PA: SAE.

McKinsey (2003), HAWK 2015: Knowledge-based changes in the automotive value chain, New York: McKinsey \& Co.

McKinsey (2009), Roads toward a low-carbon future: reducing CO2 emissions from passenger vehicles in the global road transportation system, New York: McKinsey \& Co. Inc.

Mazzucato, M. (2013) The Entrepreneurial State; Debunking Public vs Private Sector Myths, London: Anthem.

Mitchell, W., C. Borroni-Bird and L. Burns (2009), Reinventing the Automobile; Personal Urban Mobility for the $21^{\text {st }}$ Century, Cambridge MA: MIT Press.

Nieuwenhuis, P. (1994), 'The long-life car: investigating a motor industry heresy' in: P. Nieuwenhuis and P.Wells (eds.), Motor Vehicles in the Environment; Principles and Practice, Chichester: John Wiley \& Sons,153-172.

Nieuwenhuis, P. (2008), 'From banger to classic - a model for sustainable car consumption?', International Journal of Consumer Studies, 32 (6), November, 648-655.

Nieuwenhuis P (2014), Sustainable Automobility; Understanding the Car as a Natural System, Cheltenham: Edward Elgar.

Nieuwenhuis, P. and P. Wells (2003), The Automotive Industry and the Environment; A technical, business and social future, Cambridge: Woodhead.

Nieuwenhuis, P \& Wells, P (2007) The all-steel body as a cornerstone to the foundations of the mass production car industry, Industrial and Corporate Change, Vol. 16, Nr. 2, 183-211, doi:10.1093/icc/dtm001

Nieuwenhuis, P. and P. Wells (2009), Car Futures: Rethinking the Automotive Industry Beyond the American Model, www.trendtracker.co.uk.

Newman, Wells and Nieuwenhuis (2014) The rural electric vehicle, Journal of Sustainable Mobility, Issue 1, Vol. 1, May, pp.

Newman, D., Wells, P., Nieuwenhuis, P., Donovan, C. And Davies, H. (2014), Learning from Electric Cars as Socio-technical Mobility Experiments - Where next?, Transfers, Vol.4, Issue 2, Summer, 23-41; doi: 10.3167/TRANS.2014.040203.

Newman, D., Wells, P., Nieuwenhuis, P., Davies, H. and Donovan, C. (2014), Urban, suburban or rural - where is the best place for electric vehicles?, International Journal of Automotive Technology and Management, Vol. 14, nos. 3/4, 306-323.

O'Sullivan, M. (2017) Windfall; How the New Energy Abundance Upends Global Politics and Strengthens America's Power, New York: Simon \& Schuster.

Obermoller, A. (2013) Innovation failure: losing sight of the big picture, International Journal of Entrepreneurship and Innovation, 14(4), 301-306.

Peattie, K. (1995), Environmental Marketing Management: Meeting the Green Challenge. London: Prentice Hall. 
Peattie, K. (1999), 'Trappings versus substance in the greening of marketing planning', Journal of Strategic Marketing, 7, 131-148.

Peters, S. and Coles, A. (2010) Technological entrepreneurship and firm strategy: the development and commercialization of the Ballard fuel cell, The International Journal of Entrepreneurship and Innovation, 11(1), 79-88.

Rajala, R. and Westerlund, M. (2007) Business models - a new perspective on firms' assets and capabilities, The International Journal of Entrepreneurship and Innovation, 8(2), 115125.

Reisch, L. (2005/2006), 'The cultivation of sustainability', The International Journal of Environmental, Cultural, Economic \& Social Sustainability, 1 (3), 165-172.

Riversimple (2017) How the business works: https://www.riversimple.com/how-thebusiness-works/ accessed 15/9/17.

Sanne, C. (2002) Willing consumers - or locked-in? Policies for a sustainable consumption, Ecological Economics, 42, 1-2, August, 273-287.

Shulock, C. and E. Pike with A. Lloyd and R. Rose (2011) Vehicle Electrification Policy Study; Task 4 Report: Complementary Policies, Washington DC: The International Council on Clean Transportation.

Sperling, D. and Cannon, J. (eds. 2007) Driving Climate Change; Cutting Carbon from Transportation, Amsterdam: Academic Press.

Steinhilber, S., Wells, P. and Thankappan, S. (2013) Socio-technical inertia: understanding the barriers to electric vehicles, Energy Policy, 60, 531-539.

Truffer, B., Schippl, J. and Fleischer, T. (2017) Decentering technology in technology assessment: prospects for socio-technical transitions in electric mobility in Germany, Technological Forecasting and Social Change, 122, September, 34-48.

Van Gilluwe, F. and Rogers, K. (2014) Tesla Model S; Best Car Ever!, Mountain View CA: FAQware.

Wakefield, E. (1993) History of the Electric Automobile; Battery-only Powered Cars, Warrendale, PA: SAE.

Watkins, L. (1991) Air Pollution from Road Vehicles; TRRL State of the Art Review 1, London: HMSO

Wells, P. (2008) Alternative business models for a sustainable automotive industry, Chapter 5 pp 80-98, in Tukker, A. et al. (eds) System Innovation for Sustainability 1: perspectives on radical changes to sustainable consumption and production, Sheffield: Greenprint.

Wells, P. (2013) Business Models for Sustainability, Cheltenham, Edward Elgar.

Wells, P. (2016, in press) Degrowth and techno-business model innovation: the case of Riversimple, Journal of Cleaner Production, published on-line:

http://dx.doi.org/10.1016/i.jclepro.2016.06.186. 
Wells, P. and Nieuwenhuis, P. (2012) Transition failure: understanding continuity in the automotive industry, Technological Forecasting and Social Change,

DOI:10.1016/j.techfore.2012.06.008. $27^{\text {th }}$ July 2012

Wells, P., Nieuwenhuis, P. \& Orsato, R (2012), The nature and causes of inertia in the automotive industry: Regime stability and non-change, in Geels, F., Kemp, R., Dudley, G. and Lyons, G. (eds) Automobility in Transition? A Socio-Technical Analysis of Sustainable Transport, Vol.2 of Routledge Studies in Sustainability Transition, New York: Routledge; ISBN 978-0-415-88505-8.

Wells, P. and Nieuwenhuis, P. (2015) EV Business models in a wider context: balancing change and continuity in the automotive industry, in: Beeton, D. and Meyer, G. (eds) Electric Vehicle Business Models; Global Perspectives, Springer: ISBN: 978-3-319-12243-4.

Williams, A. (2006), 'System innovation in the automotive industry' in: P. Nieuwenhuis, P. Vergragt and P. Wells (eds.), The Business of Sustainable Mobility; From Vision to Reality, Sheffield: Greenleaf, 80-91. 